\title{
Por uma medicina científica e humanista: a atualidade da obra de Rudolf Virchow
}

\section{Towards a scientific, humanist medicine: the relevance of Rudolf Virchow today}

\author{
Márcio Magalhães \\ Doutorando do Programa de Pós-graduação em História das Ciências e da Saúde/ \\ Casa de Oswaldo Cruz/Fundação Oswaldo Cruz \\ marcmagand@gmail.com
}

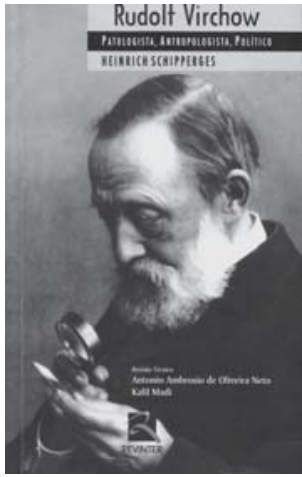

SCHIPPERGES, Heinrich. Rudolf Virchow:

patologista,

antropologista, político.

Rio de Janeiro: Revinter. 2010. 164p.
$\mathrm{P}$ ara um grupo relativamente reduzido de médicos e historiadores talvez pareça redundante ou banal utilizar o adjetivo polivalente para referir-se à figura de Rudolf Virchow (1821-1902). Quem dentro desse limitado grupo de especialistas não saberia que o médico alemão, nascido em Schivelbein (pertencente à Polônia desde 1945), ignorando as supostas fronteiras do conhecimento, atuou como naturalista, político, antropologista e filósofo furtivo? Fora desses círculos restritos, no entanto, é provável que Virchow não seja sequer conhecido. Teria sido ele um excêntrico, um generalista pouco afeito às especializações que começaram a se definir entre a segunda metade do século XIX e a primeira do século seguinte?

Interessado em retificar o que lhe pareceu um lapso na história da ciência, Heinrich Schipperges produziu um sucinto perfil biográfico intitulado Rudolf Virchow: patologista, antropologista, político (publicado na Alemanha em 1994). A intenção desse trabalho, agora disponível em língua portuguesa, é apresentar a vasta e complexa obra daquele múltiplo personagem oitocentista.

Considerado o mais importante sanitarista alemão do século XIX e reconhecido como o Pai da Patologia Celular, Virchow teve destacada atuação política em sua época. Republicano desde a juventude, integrou a Organização Democrática da Associação dos Trabalhadores em 1848 (ano-base das breves ondas revolucionárias que passaram para a história como a Primavera dos Povos), tornou-se membro, a partir de 1859, da Câmara Municipal de Berlim (onde desempenhou papel fundamental nas reformas sanitárias da cidade) e ajudou a fundar o Partido Progressista Alemão, em 1861, mesmo ano em que foi eleito para a Câmara dos Deputados da Prússia. Por conta de seus posicionamentos progressistas, entrou em rota de colisão com o poderoso e reacionário Otto von Bismarck (1815-1898), que chegou a convidá-lo para um duelo de pistolas.

Virchow valorizou sobremaneira os problemas sociais e culturais na causação de doenças. O sanitarista corroborava a divisão das epidemias em naturais e culturais, sendo a história destas últimas, segundo ele, a história dos distúrbios experimentados pela cultura, das 
perturbações diversas que motivavam reviravoltas na sociedade. Mas havia algo mais: a célula, que ele passou a considerar a forma última e elementar da vida, o 'motor da vida' e o 'motor da doença', organizava-se em formas específicas, num arranjo social, coletivo, que dava origem a grupos de tecidos. A partir desse pressuposto, passou a defender a ideia de que formações patológicas eram decorrentes de gerações inadequadas desses tecidos (heterometria, hipertrofia, hiperplasia etc.). Die Cellularpathologie (A patologia celular), sua obra seminal, foi publicada em 1858.

Heinrich Schipperges - ele mesmo médico, filósofo e historiador - empenhou-se na construção de uma narrativa que pudesse contemplar as diversas atividades desenvolvidas por Rudolf Virchow. O que uniria, afinal, política, medicina e antropologia (tida por nosso personagem como uma ciência humana abrangente, uma doutrina do homem a ser elaborada pela medicina científica)? A ideia de uma ciência unificada, vislumbrada pelo sanitarista alemão e por muitos de seus contemporâneos, perpassa o trabalho de Schipperges. Para os homens do Oitocentos, o método científico seria capaz de promover a unificação da ciência. Somava-se a essa expectativa o entusiasmo com a ideia de progresso, reforçada pela obra A origem das espécies (1858), de Charles Darwin (1809-1882). A teoria da evolução por meio da seleção natural, defendida por Darwin, teve o mérito de trazer o homem para dentro do esquema da evolução biológica, fato responsável pela abolição das divisões entre ciências naturais e humanas. Virchow respirou e colaborou com essa atmosfera universalista.

O livro de Schipperges, que teve nos trabalhos de Erwin Ackerknecht (1953) e de Manfred Vasold (1988) duas importantes referências, traz uma quantidade considerável de citações de trechos da obra de Virchow. Segundo o autor, sua intenção era "dar voz o máximo possível", colher um "testemunho pessoal" do personagem. Em alguns momentos tem-se a impressão de um Rudolf Virchow um tanto isolado, heroico. Os posicionamentos do personagem em relação à obra de Darwin e à bacteriologia, apesar de mencionados, são pouco explorados pelo autor. Ainda assim, vale ressaltar que o livro em questão tem o mérito de permitir ao público brasileiro maior familiaridade com a vida e a obra de um dos grandes médicos sanitaristas do século XIX.

\section{REFERÊNCIAS}

ACKERKNECHT, Erwin.

Rudolf Virchow: doctor, statesman, anthropologist. Madison: University of Wiscosin Press, 1953.
VASOLD, Manfred.

Rudolf Virchow: der grosse Arzt und Politiker. Stuttgart: Deutsche Verlags-Anstalt. 1988. 